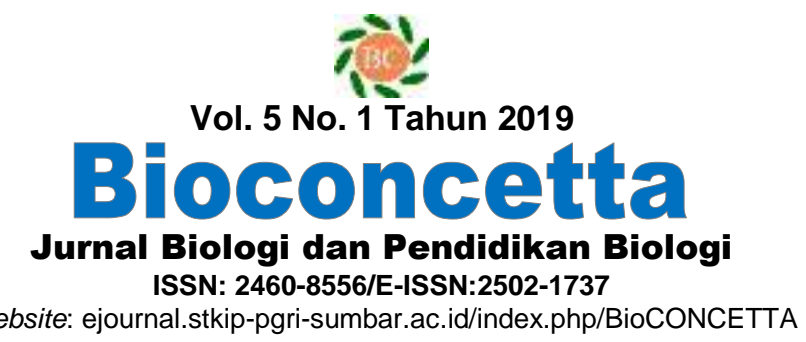

\title{
Efektivitas Penuntun Praktikum Biologi Umum Berbasis Pendekatan Saintifik Terhadap Kompetensi Mahasiswa
}

\author{
Nurul Fauziah \\ Program Studi Pendidikan Biologi Universitas Islam Riau \\ Jl. Kaharudin Nasution No. 113, Kota Pekanbaru, Riau (28284) Indonesia. \\ Email: fauziahnurul@edu.uir.ac.id
}

Info Artikel

Sejarah Artikel

Diterima:

13 Juni 2019

Disetujui:

13 Juni 2019

Dipublikasikan:

31 Agustus 2019

Kata Kunci:

Efektifitas,

Pendekatan Saintifik,

Penuntun Praktikum

Keywords:

Effectiveness,

Practicum Guidance,

Scientific Approach

\begin{abstract}
Abstrak
Penelitian ini bertujuan untuk mengetahui efektivitas penuntun praktikum biologi umum berbasis pendekatan saintifik terhadap kompetensi mahasiswa. Penelitian ini merupakan penelitian eksperimen dengan menggunakan uji dua rata-rata. Instrumen pengumpulan data dalam penelitian ini adalah tes hasil belajar untuk mengukur kompetensi kognitif, dan lembar observasi untuk afektif, dan psikomotor. Uji coba dilakukan pada 29 orang mahasiswa Program Studi Pendidikan Matematika yang mengambil mata kuliah biologi umum di STKIP PGRI Sumatera Barat. Hasil penelitian ini menunjukkan bahwa penuntun praktikum biologi umum berbasis pendekatan saintifik sangat efektif. Rata-rata kompetensi koginitif kelas eksperimen lebih tinggi $(84,82)$ dibandingkan kelas kontrol $(52,74)$, rata-rata kompetensi afektif kelas eksperimen lebih tinggi $(88,30)$ dibandingkan kelas kontrol $(68,08)$, dan rata-rata kompetensi psikomotor kelas eksperimen lebih tinggi $(87,90)$ dibandingkan kelas kontrol $(64,82)$. Kesimpulannya adalah penuntun praktikum biologi umum berbasis pendekatan saintifik untuk mahasiswa sudah efektif.
\end{abstract}

\begin{abstract}
This research aims to determine the effectiveness of general biological practicum guidance based on scientific approaches to student competence. This research is an experimental study using a two-onaverage test. The data collection instruments in this study are test learning outcomes for measuring cognitive competence, and observation sheets for affective, and psychomotor. The try out were conducted in 29 students of Mathematics Education Study Program was taking a general biology course at STKIP PGRI West Sumatera. The results of this study show that general biological practicum guidance based on scientific approaches to students is very effective. The average coginitive competency of the experimental class is higher (84.82) than the control class (52.74), the average experimental class affective competence (88.30) is in the control class (68.08), and on average the class psychomotor competence Higher experiment (87.90) than the control class (64.82). The conclusion is a general biological practicum guide based on scientific approaches for students is effective.
\end{abstract}




\section{PENDAHULUAN}

Pembelajaran merupakan proses interaksi antara peserta didik dengan pendidik dan sumber belajar pada suatu lingkungan belajar (Niken dan Gusti, 2018). Salah satu proses pembelajaran adalah kegiatan praktikum.

Praktikum merupakan salah satu kegiatan belajar mengajar yang bertujuan untuk memantapkan pengetahuan peserta didik terhadap materi mata kuliah melalui aplikasi, analisis, sintesis, dan evaluasi teori yang dipelajari, baik di dalam laboratorium maupun di lapangan. Kegiatan praktikum tidak hanya membuktikan teori yang dipelajari peserta didik, tapi juga berfungsi untuk melatih dan meningkatkan proses sains. Praktikum wajib diikuti oleh setiap peserta didik (Nurmawati dan Sulistiana, 2011). Kegiatan praktikum diselenggarakan dalam bentuk pengamatan dan percobaan di dalam ataupun di luar laboratorium.

Penuntun praktikum merupakan fasilitas praktikum yang membantu peserta didik melaksanakan kegiatan praktikum (Killinct, 2007). Penuntun praktikum ditujukan untuk membantu dan menuntun peserta didik sebagai praktikan agar dapat bekerja secara kontinu dan terarah, serta dapat mengembangkan kreatifitas dan sikap ilmiah dalam setiap eksperimen yang dilakukan. Penuntun praktikum biologi umum merupakan salah satu bahan ajar yang digunakan untuk memantapkan konsep dan teori yang diperoleh peserta didik dari proses perkuliahan biologi umum. Hal ini sejalan dengan penelitian (Nengsi, 2018) yang mengungkapkan bahwa penggunaan media dalam proses pembelajaran Biologi dapat menumbuhkan kembali perhatian peserta didik terhadap materi pelajaran.

Kegiatan praktikum dalam pelaksanaannya disesuaikan dengan prosedur, bahan, dan alat yang terdapat pada penuntun praktikum, agar tercapai kompetensi dasar dari mata kuliah yang dipraktikumkan. Rustaman (2002) menyatakan bahwa untuk menunjang keberhasilan dan optimalisasi kegiatan praktikum diantaranya, melibatkan peserta didik, kurikulum, peralatan, penuntun praktikum, dan sistem evaluasi penuntun praktikum yang digunakan sebagai panduan tahapan kerja praktikum bagi peserta didik sebagai praktikan dan pendidik sebagai pembimbing.

Penuntun praktikum biologi umum merupakan salah satu bahan ajar yang digunakan untuk memantapkan konsep dan teori yang diperoleh peserta didik dari proses perkuliahan biologi umum. Mata kuliah biologi umum memiliki tujuan untuk memberi wawasan tentang biologi sebagai ilmu dan cakupan persoalan biologi secara lebih utuh. Karena misinya adalah untuk membuka wawasan, maka materi kajiannya masih bersifat global dan menyangkut tema-tema besar biologi. Peserta didik setelah mengikuti kegiatan praktikum biologi umum diharapkan memiliki pengalaman dasar yang lebih mantap dan dapat 
digunakan untuk mempelajari biologi lebih lanjut serta memberikan keterampilan dasar dalam memecahkan masalah-masalah biologi berdasarkan sikap dan prosedur ilmiah.

Hasil observasi dan wawancara yang telah dilakukan mengungkapkan permasalahan yang terdapat pada praktikum biologi umum tersebut. Peserta didik sebagai praktikan untuk meningkatkan kompetensi dan keahlian dalam melaksanakan metode ilmiah, harus memberikan kontribusi kerja selama kegiatan praktikum, tidak boleh hanya mengandalkan teman satu kelompok saja. Pencapaian tujuan praktikum akan sulit dilakukan, jika peserta didik tidak terbiasa melakukan kegiatan proses sains sendiri. Salah satu usaha yang dapat dilakukan untuk membiasakan peserta didik melakukan proses sains, diantaranya melalui kegiatan praktikum yang didukung oleh penuntun praktikum berbasis pendekatan saintifik.

Penuntun praktikum berbasis pendekatan saintifik adalah salah satu penuntun yang dapat mengasah kemampuan peserta didik sesuai dengan tingkat kemampuan berpikirnya. Hal ini dikarenakan penuntun praktikum berbasis pendekatan saintifik akan merujuk pada bukti-bukti dari objek yang di observasi, empiris, dan terukur dengan prinsip-prinsip penalaran yang spesifik. Hal ini berkaitan dengan karakteristik pendekatan saintifik yang umumnya memuat serial aktivitas mengamati, menanya, melakukan eksperimen, menalar dan mengkomunikasikannya (Kementrian
Pendididikan dan Kebudayaan, 2013). Ini juga sejalan dengan penelitian yang dilakukan Roza (2015), yang hasilnya menunjukkan bahwa penuntun praktikum biologi berbasis pendekatan saintifik untuk MTs/ SMP Kelas VII Semester II memperlihatkan adanya peningkatan pada kompetensi kognitif, afektif dan psikomotor melalui aktivitas kerja ilmiah yang dilakukan oleh peserta didik. Hal ini juga didukung oleh hasil penelitian Suprijono (2016) yang mengungkapkan bahwa penggunaan pendekatan saintifik pada kelompok kelas eksperimen memberikan pengaruh terhadap prestasi belajar siswa sebesar 94,1\% sedangkan penggunaan metode ceramah pada kelompok kelas kontrol memberikan prestasi belajar sebesar $90,5 \%$.

Keunggulan pendekatan saintifik menurut Daryanto (2014) adalah untuk meningkatkan kemampuan intelektual, khususnya kemampuan dalam menyelesaikan suatu masalah secara sistematik. Terciptanya kondisi pembelajaran dimana peserta didik merasa bahwa belajar adalah suatu kebutuhan, sehingga diperoleh hasil belajar yang tinggi, serta melatih peserta didik mengkomunikasikan ideide, khususnya dalam menuliskan artikel ilmiah, dan untuk mengembangkan karakter. Hal ini juga sejalan dengan penelitian Setiawati, dkk (2018), yang hasilnya menunjukkan bahwa hasil belajar siswa yang menggunakan pendekatan saintifik lebih baik dari hasil belajar siswa yang tidak menggunakan pendekatan saintifik dalam 
pembelajaran IPA di kelas IV SD Negeri 10 Lambung Bukit Kecamatan Pauh. Berdasarkan latar belakang masalah di atas, tujuan penelitian ini adalah mengungkapkan efektifitas penuntun praktikum biologi umum berbasis pendekatan saintifik terhadap kompetensi mahasiswa.

\section{BAHAN DAN METODE}

Uji coba lapangan dilakukan pada 29 orang mahasiswa jurusan pendidikan matematika yang sedang mengambil mata kuliah biologi umum di program studi Pendidikan Biologi di STKIP PGRI Sumatera Barat. Instrumen yang digunakan untuk mengumpulkan data keefektivan terdiri dari lembar observasi untuk kompetensi afektif dan psikomotor dan tes hasil belajar untuk mengukur kompetensi kognitif.

Analisis Kompetensi Kognitif dilakukan dengan uji normalitas yang bertujuan untuk melihat apakah data kedua kelas sampel terdistribusi normal atau tidak. Untuk menguji normalitas digunakan uji Lilliefors (Sudjana, 2005). Kemudian dilakukan uji homogenitas berguna untuk melihat apakah data memiliki varians yang homogen atau tidak. Untuk menguji homogenitas dilakukan uji F. Sesuai dengan langkah-langkah yang dikemukakan oleh Sudjana (2005). Dan yang terakhir dilakukan uji hipotesis. Setelah melakukan uji normalitas dan uji homogenitas maka dilakukan uji hipotesis. Untuk menguji hipotesis digunakan uji kesamaan dua rata-rata. Dari analisis yang dilakukan diperoleh bahwa kelas kontrol dan kelas eksperimen terdistibusi normal dan memiliki varians yang homogen, maka digunakan uji $\mathrm{t}$ seperti yang dikemukakan Sudjana (2005). Kriteria penguji yang dipergunakan harga $t$ dibandingkan dengan $t$ tabel, yang terdapat pada tabel distribusi $t_{1 \text { - }}$ $0,5 \alpha<t<t_{1-0,5 \alpha}$ pada taraf signifikan 0,05 untuk harga lainnya Ho di tolak.

Uji Hipotesis untuk kompetensi afektif dan psikomotor dengan menggunakan uji Mann Withney atau Uji-U. Setelah memperoleh nilai $\mathrm{Z}$ maka langkah selanjutnya mencari nilai tabel $\mathrm{Z}$ dua arah dengan taraf signifikan $\alpha=0,05$ dengan ketentuan nilai statistik uji $Z_{\text {hitung }}>Z_{\text {tabel. }}$. Artinya diperoleh $Z_{\text {hitung }}>Z_{\text {tabel, }}$ maka hipotesis diterima (Yusuf, 2013).

\section{HASIL DAN PEMBAHASAN}

Setelah dilakukannya eksperimen, maka dijabarkan hasil kompetensi kognitif, kompetensi afektif dan kompetensi psikomotor sebagai berikut.

Rata-rata kompetensi kognitif mahasiswa pada kelas eksperimen lebih tinggi daripada kelas kontrol. Lihat Tabel 1.

Hasil uji normalitas kelas eksperimen dan kelas kontrol dapat dilihat pada Tabel 3, dan untuk hasil uji homogenitas dapat dilihat pada Tabel 4. Selanjutnya untuk mengetahui ada tidaknya pengaruh penggunaan penuntun praktikum biologi umum berbasis saintifik terhadap kompetensi kognitif, dapat dilihat hasilnya pada Tabel 5. 
Tabel 1. Hasil Kompetensi Kognitif Mahasiswa Kelas Kontrol dan Kelas Eksperimen

\begin{tabular}{lcccccc}
\hline \multicolumn{1}{c}{ Kelas } & $\mathrm{N}$ & $\mathrm{Xmin}$ & $\mathrm{Xmax}$ & $\bar{X}$ & $\mathrm{~S}$ & $\mathrm{~S}^{2}$ \\
\hline Kontrol & 31 & 35 & 75 & 52,74 & 9,47 & 89,68 \\
Eksperimen & 29 & 70 & 95 & 84,82 & 8,18 & 66,91 \\
\hline
\end{tabular}

Tabel 2. Uji Normalitas Kompetensi Kognitif Mahasiswa Kelas Kontrol dan Kelas Eksperimen

\begin{tabular}{lcccccc}
\hline \multicolumn{1}{c}{ Kelas } & $\mathrm{N}$ & $\bar{X}$ & $\begin{array}{c}\text { Standar } \\
\text { Deviasi }\end{array}$ & $\mathrm{L}_{0}$ & $\mathrm{~L}_{\text {tabel }}$ & Kesimpulan \\
\hline Kontrol & 31 & 52,74 & 9,47 & 0,179 & 0,15 & Normal \\
Eksperimen & 29 & 84,82 & 8,18 & 0,112 & 0,02 & \\
\hline
\end{tabular}

Tabel 3. Uji Homogenitas Kompetensi Kognitif Mahasiswa Kelas Kontrol dan Kelas Eksperimen

\begin{tabular}{lccccccc}
\hline \multicolumn{1}{c}{ Kelas } & $\mathrm{N}$ & $\bar{X}$ & $\mathrm{~S}$ & $\mathrm{~S}^{2}$ & $\mathrm{~F}_{\text {hitung }}$ & $\mathrm{F}_{\text {tabel }}$ & Kes. \\
\hline Kontrol & 31 & 52,74 & 9,47 & 89,68 & 1,34 & 1,84 & Homogen \\
Eks & 29 & 84,82 & 8,18 & 66,91 & & & \\
\hline
\end{tabular}

Tabel 4. Nilai Rata-rata dan Uji Hipotesis Kompetensi Kognitif Mahasiswa Kelas Kontrol dan Kelas Eksperimen

\begin{tabular}{lccccccc}
\hline \multicolumn{1}{c}{ Kelas } & $\mathrm{N}$ & $\bar{X}$ & $\mathrm{~S}$ & $\mathrm{~S}^{2}$ & $\mathrm{t}_{\text {hitung }}$ & $\mathrm{t}_{\text {tabel }}$ & Kes. \\
\hline Kontrol & 31 & 52,74 & 9,47 & 89,68 & 15,27 & 1,67 & Hipotesis Diterima \\
Eks & 29 & 84,82 & 8,18 & 66,91 & & & \\
\hline
\end{tabular}

Diketahui dari Tabel 2 nilai $\mathrm{L}_{0}$ kelas kontrol $<\mathrm{L}_{\text {tabel}}$, nilai $\mathrm{L}_{0}$ kelas eksperimen $<\mathrm{L}_{\text {tabel }}$ pada tingkat signifikan 5\%. Sehingga dapat disimpulkan uji normalitas kompetensi kognitif mahasiswa pada kedua kelas berdistribusi normal.Diketahui dari Tabel $3 \mathrm{~F}_{\text {hitung }}<\mathrm{F}_{\text {tabel }}$ yaitu $1,34<1,84$ dengan taraf kepercayaan $0,95 \%$ atau $\alpha$ 0,05\%, dengan demikian kompetensi kognitif

kedua sampel mempunyai varian yang homogen. Pada Tabel 4 dapat dilihat hasil kompetensi kognitif mahasiswa diperoleh $t_{\text {hitung }} 15,27$, sedangkan $t_{\text {tabel }} 1,67$. Dari data tersebut diperoleh $t_{\text {hitung }}>t_{\text {tabel }}$ berarti hipotesis diterima.
Penggunaan penuntun praktikum biologi umum berbasis pendekatan saintifik memberikan pengaruh positif terhadap kompetensi kognitif belajar mahasiswa. Hasil kompetensi kognitif kelas eksperimen yang menggunakan penuntun praktikum berbasis pendekatan saintifik lebih tinggi dibandingkan kelas kontrol yang tidak menggunakan penuntun praktikum berbasis pendekatan saintifik.

Kompetensi kognitif kelas eksperimen lebih tinggi dari kelas kontrol karena pendekatan saintifik bersifat sistematis dan dapat meningkatkan kemampuan berpikir mahasiswa, sehingga meningkatkan pemahaman terhadap materi dan kegiatan praktikum yang telah 
dilakukan. Hal tersebut akan meningkatkan kompetensi koginitif mahasiswa. Sejalan dengan penelitian Roza (2015) bahwa pendekatan saintifik dapat meningkatkan kompetensi kognitif peserta didik. Sedangkan penuntun praktikum yang tidak menggunakan pendekatan saintifik tidak bersifat sistematis sehingga kurang meningkatkan kognitif mahasiswa. Selain itu, hasil penelitian yang dilakukan Hastuti (2017) juga mengungkapkan bahwa kecenderungan prestasi belajar IPA pokok bahasan peristiwa alam yang terjadi di Indonesia dan dampaknya bagi makhluk hidup dan lingkungan kelas V SD Jurugentong, Banguntapan, Bantul, Yogyakarta yang pembelajarannya dengan pendekatan saintifik termasuk kategori tinggi dengan nilai rata-rata 18,063 dan dengan pendekatan konvensional termasuk kategori sedang dengan nilai rata-rata 14,563.

Untuk kompetensi afektif mahasiswa kelas kontrol dan kelas eksperimen dapat dilihat pada Tabel 5. Selanjutnya untuk mengetahui ada tidaknya pengaruh penggunaan penuntun praktikum biologi umum berbasis saintifik, hasil dapat dilihat pada Tabel 6.

Tabel 5. Nilai Kompetensi Afektif Mahasiswa Kelas Kontrol dan Kelas Eksperimen

\begin{tabular}{lccccc}
\hline \multicolumn{1}{c}{ Kelas } & $\mathrm{N}$ & $\mathrm{X} \min$ & $\mathrm{X} \max$ & $\bar{X}$ & Predikat \\
\hline Kontrol & 31 & 59,04 & 75,0 & 68,08 & Baik \\
Eksperimen & 29 & 83,30 & 95,8 & 88,30 & Sangat Baik \\
\hline
\end{tabular}

Tabel 6. Nilai Rata-rata dan Uji Hipotesis Kompetensi Afektif Mahasiswa Kelas Kontrol dan Kelas Eksperimen

\begin{tabular}{lccccccc}
\hline \multicolumn{1}{c}{ Kelas } & $\mathrm{N}$ & $\bar{X}$ & $\mathrm{~S}$ & $\mathrm{~S}^{2}$ & $\mathrm{Z}_{\text {hitung }}$ & $\mathrm{Z}_{\text {tabel }}$ & Kes. \\
\hline Kontrol & 31 & 68,08 & 9,47 & 89,68 & 5,74 & 1,96 & Hipotesis \\
Eks & 29 & 88,30 & 8,18 & 66,91 & & & Diterima \\
\hline
\end{tabular}

Diketahui dari Tabel 6 kompetensi afektif mahasiswa memperoleh $Z_{\text {hitung }} 5,74$, sedangkan $\mathrm{Z}_{\text {tabel }}$ 1,96. Dari data tersebut diperoleh $Z_{\text {hitung }}>Z_{\text {tabel }}$ berarti hipotesis diterima.

Kompetensi afektif mahasiswa kelas eksperimen yang menggunakan penuntun praktikum biologi umum berbasis pendekatan saintifik lebih tinggi daripada kelas kontrol yang tidak menggunakan penuntun praktikum biologi umum berbasis pendekatan saintifik.
Hasil pengamatan kompetensi afektif yang dilakukan oleh observer mendapatkan hasil yang positif. Penilaian kompetensi afektif kelas eksperimen yang menggunakan penuntun praktikum berbasis pendekatan saintifik lebih baik daripada kelas kontrol yang tidak menggunakan penuntun praktikum berbasis pendekatan saintifik.

Peningkatan kompetensi afektif ini disebabkan karena proses pembelajaran yang menggunakan pendekatan saintifik akan 
membiasakan mahasiswa untuk bersikap sesuai dengan sikap ilmiah, seperti toleransi, berpikir kritis, berpikir analitis, berpikir sistematis, teliti, memiliki rasa ingin tahu yang tinggi, disiplin, dan bertanggungjawab. Pendekatan saintifik telah meningkatkan kompetensi afektif mahasiswa dalam kegiatan praktikum menjadi lebih baik. Hal ini sejalan dengan pendapat Hosnan (2014) bahwa pendekatan saintifik dapat mengembangkan sikap teliti, berpikir sistematis, berpikir analitis, serta bertanggungjawab.

Kompetensi selanjutnya yang diuji adalah kompetensi psikomotor. Untuk kompetensi psikomotor mahasiswa kelas kontrol dan kelas eksperimen dapat dilihat pada Tabel 7. Selanjutnya untuk mengetahui ada tidaknya pengaruh penggunaan penuntun praktikum biologi umum berbasis saintifik, hasil dapat dilihat pada Tabel 8.

Tabel 7. Nilai Kompetensi Psikomotor Mahasiswa Kelas Kontrol dan Kelas Eksperimen

\begin{tabular}{lccccc}
\hline \multicolumn{1}{c}{ Kelas } & N & Xmin & X max & $\bar{X}$ & Predikat \\
\hline Kontrol & 31 & 56,30 & 72,90 & 64,82 & Baik \\
Eksperimen & 29 & 82,30 & 93,80 & 87,90 & Sangat Baik \\
\hline
\end{tabular}

Tabel 8. Nilai Rata-rata dan Uji Hipotesis Kompetensi Psikomotor Mahasiswa Kelas Kontrol dan Kelas Eksperimen

\begin{tabular}{lccccccc}
\hline \multicolumn{1}{c}{ Kelas } & $\mathbf{N}$ & $\bar{X}$ & $\mathbf{S}$ & $\mathbf{S}^{2}$ & $\mathbf{Z}_{\text {hitung }}$ & $\mathbf{Z}_{\text {tabel }}$ & Kes. \\
\hline Kontrol & 31 & 64,82 & 9,47 & 89,68 & 5,74 & 1,96 & Hipotesis \\
Eks & 29 & 87,90 & 8,18 & 66,91 & & & Diterima \\
\hline
\end{tabular}

Diketahui dari Tabel 8 kompetensi psikomotor mahasiswa memperoleh $Z_{\text {hitung }} 5,74$, sedangkan $\mathrm{Z}_{\text {tabel }}$ 1,96. Dari data tersebut diperoleh $\mathrm{Z}_{\text {hitung }}>\mathrm{Z}_{\text {tabel }}$ berarti hipotesis diterima.

Rata-rata kompetensi psikomotor mahasiswa pada kelas eksperimen lebih tinggi dibandingkan kelas kontrol. Hal ini menunjukkan bahwa kompetensi psikomotor mahasiswa kelas eksperimen yang menggunakan penuntun praktikum biologi umum berbasis pendekatan saintifik lebih tinggi daripada kelas kontrol yang tidak menggunakan penuntun praktikum biologi umum berbasis pendekatan saintifik.
Hasil pengamatan kompetensi psikomotor yang dilakukan oleh observer mendapatkan hasil yang positif. Penilaian kompetensi psikomotor kelas eksperimen yang menggunakan penuntun praktikum berbasis pendekatan saintifik lebih baik daripada kelas kontrol yang tidak menggunakan penuntun praktikum berbasis pendekatan saintifik. Peningakatan kompetensi psikomotor ini disebabkan karena proses pembelajaran yang menggunakan pendekatan saintifik akan mengembangkan keterampilan bertanya, keterampilan mengeluarkan pendapat, keterampilan dalam melakukan percobaan, keterampilan 
berkomunikasi, dan kerampilan menuliskan hasil laporan kegiatan praktikum. Hal ini sejalan dengan pendapat Sani (2014) bahwa pendekatan saintifik dapat mengembangkan keterampilan bertanya, mengeluarkan pendapat dan berkomunikasi dengan menggunakan bahasa yang baik dan benar.

\section{SIMPULAN}

Penuntun praktikum biologi umum berbasis pendekatan saintifik sudah efektif karena memberikan pengaruh positif dalam meningkatkan kompetensi kognitif, kompetensi afektif, dan kompetensi psikomotor mahasiswa.

\section{DAFTAR PUSTAKA}

Daryanto. 2014

Pembelajaran

Pendekatan

Kurikulum 2013. Yogyakarta: Gava Media.

Hastuti, LD. 2017. Pengaruh Pendekatan Saintifik terhadap Prestasi Belajar IPA. Trihayu: Jurnal Pendidikan ke-SD-an, 3(2) 2017: 107-111. https://media.neliti.com/media/p ublications/259114-pengaruhpendekatan-saintifik-terhadap-pfae0d063.pdf. (Online) Diakses Juni 2019.

Hosnan. 2014. Pendekatan Saintifik Dan Konstektual Dalam Pembelajaran Abad 21 Kunci Sukses Implementasi Kurikulum 2013. Jakarta: Ghalia Indonesia.

Kementrian Pendidikan dan Kebudayaan. 2013. Pendekatanpendekatan Ilmiah dalam Pembelajaran. Diklat Guru dalam Rangka Implementasi
Kurikulum 2013; Konsep Pendekatan Saintifik. Bandung.

Killinct, A. 2007. The Opinioin of Turkish Highh School Pipils on Inquiry Based Laboratory Activities. Gazi University Education Faculty Department of Biology Education. http://www.lojet.net/articles/646. pdf. (Online) Diakses Juni 2015.

Nengsi, S. 2018. Pengembangan LKS dilengkapi Permainan Edukatif pada Materi Bahan Kimia dalam Kehidupan Sehari-hari Siswa Kelas VIII. Jurnal Bioconcetta, 4 (2) 2018: 14-28. http:// ejournal.stkip-pgri-sumbar. ac. id/ index.php/BioCONCETTA/ article/view/2997/PDF. (Online). Diakses 16 Agustus 2019.

Niken., dan Gusti, FR. 2018. Pengembangan Modul Pembelajaran Berorientasi Keterampilan Proses Sains pada Mata Kuliah Biologi untuk Perkuliahan di Pergutuan Tinggi Kesehatan. Jurnal Bioconcetta, 4 (2) 2018: 1-13. http:// ejournal. stkip- pgri- sumbar. ac. id/ index. $\mathrm{php} /$ BioCONCETTA/ article/ view/ 3016/ PDF. (Online). Diakses 16 Agustus 2019.

Nurmawati, S., dan S. Sulistiana. 2011. Analisis Kompetensi dalam Penyempurnaan BMP Mata Kuliah Praktikum Taksonomi Avertebrata dan Pelaksanaan Praktikumnya di Perguruan Tinggi Mitra. http://www .pustaka. ut. ac. id/ pdf penelitian/ 81850. pdf. (Online). Diakses Agustus 2015.

Roza, RK. 2015. "Pengembangan Penuntun Praktikum Biologi Berbasis Pendekatan Saintifik untuk MTs/SMP Kelas VII 
Semester II". Tesis. Padang: Universitas Negeri Padang.

Rustaman, NY. 2002. Perencanaan dan Penilaian Praktikum di Perguruan Tinggi. Program Applied Approach Dosen UPI Tahun 2002. http://fileupi.edu/ rustaman/ perencanaan dan penilaian_. (Online). Diakses Juni 2015.

Sani, RA. 2014. Pembelajaran Saintifik Untuk Implementasi Kurikulum 2013. Jakarta: Bumi Aksara.

Setiawati, NS., Dina D., dan Neviyarni. 2018. Pengaruh Pendekatan Saintifik terhadap Hasil Belajar dalam Pembelajaran IPA di Sekolah Dasar. https://www.researchgate. net/publication/330010720_PEN GARUH_PENDEKATAN_SAI NTIFIK_TERHADAP_HASIL
BELAJAR_DALAM_PEMBEL AJARAN_IPA_DI_SEKOLAH DASAR/download. (Online) Diakses Juni 2019.

Sudjana, N. 2005. Penilaian Hasil Belajar Mengajar. Bandung: PT. Remaja Rosdakarya.

Suprijono, A. 2016. Pengaruh Pendekatan Saintifik terhadap Prestasi Belajar Siswa pada Mata Pelajaran IPS Kelas VIII E di SMP Negeri 24 Surabaya. AVATARA, e-Journal Pendidikan Sejarah. $\underline{\text { https:// }}$ jurnal mahasiswa. unesa. ac. id/index.php/avatara/article/view /16952/15407. (Online). Diakses Juni 2019.

Yusuf, M. 2013. Metode Penelitian Kuantitatif, kualitatif dan Penelitian Gabungan. Padang: UNP Press. 